\title{
NGUYÊN LÝ VÀ KỸ THUẬT \\ BƠM BÓNG ĐỐI XUNG TRONG ĐỘNG MẠCH CHỦ
}

\author{
Đoàn Đức Hoằng*, Bùi Đức Phú*, Tôn Nũ Phước Thịnh*, \\ Nguyễn Phan Huy*, Trần Chí Thành*
}

Kỹ thuật bơm bóng đối xung trong động mạch chủ (IABP: Intra Aortic Balloon Pump) là một trong những kỹ thuật hỗ trợ tuần hoàn cơ học được sử dụng phổ biến nhất cho những bệnh nhân nặng ở phòng hồi sức có bệnh lý tim mạch. Kỹ thuật này được sử dụng cho khoảng 42.000 bệnh nhân tại Mỹ vào năm 2002. Cùng với những tiến bộ khoa học kỹ thuật, các thiết bị đã được cải tiến và phát triển như kỹ thuật luồn catheter bóng vào trong động mạch chủ qua da, với đường kính của catheter được thiết kế nhỏ hơn, kỹ thuật luồn bóng khồng sử dụng kim dẫn đường, và với nhiều công đoạn tự động hóa trong quy trình kỹ thuật.

\section{Lịch sử}

Kantrowitz [1] đã ghi nhận có sự gia tăng lưu lượng vành khi làm chậm nhịp đập động mạch ở các động vật thí nghiệm vào năm 1952. Năm 1958, Harken [2] đã nghĩ đến phương pháp lấy máu qua đường động mạch dùi vào thì tâm thu và truyền nhanh trở lại lượng máu này vào thì tâm tương để điều trị suy tâm thất trái, còn được gọi là gia tăng thì tâm trương. Bốn năm sau, Moulopoulos và cộng sự [3] đã phát triển nguyên bản đầu tiên của IABP có thể bơm và xả bóng tùy thuộc vào chu chuyển tim. Năm 1968, Kantrowitz [1] đã báo cáo có sự cải thiện huyết áp hệ thống và lưu lượng nước tiểu khi sử dụng IABP cho hai bệnh nhân bi sốc tim và một trong hai bệnh nhân này đã được cứu sống. Kỹ thuật IABP qua da với loại catheter bóng với kích cỡ 8,5 - 9,5F (trước đó là loại $15 \mathrm{~F}$ ) đã được đưa vào sử dụng từ năm 1979 bởi Bergman và cộng sự. Loại IABP tự động hóa được phát triển từ năm 1986.

\section{Nguyên lý kỹ thuật bơm bóng đối xung} trong động mạch chủ
Bơm bóng đối xung trong động mạch là một thuật ngữ mô tả sự bơm bóng vào thì tâm trương và xả bóng vào giai đoạn sớm của thì tâm thu. Điều này giúp làm tăng lưu lượng vành (nhận máu vào thì tâm trương) và cải thiện tưới máu hệ thống do làm giảm kháng lực mạch máu ngoại biên* .

\section{Sinh lý bệnh của kỹ thuật IABP}

Mục tiêu đầu tiên của IABP là cải thiện hiệu suất co bóp của tâm thất khi bị suy tim qua cơ chế làm tăng lưu lượng vành để tăng cung cấp oxy cho cơ tim. những tác động hỗ trợ huyết động của liệu pháp IABP được tóm tắt trong bảng 1 . Mặc dù tác động huyết động của IABP lên thất trái nổi trội hơn, nhưng IABP cũng có thể có những tác động có lợi trên thất phải qua một cơ chế phức tạp do làm gia tăng lưu lượng tưới máu cơ tim thất phải, giảm gánh thất trái nên làm giảm áp lực nhĩ trái và áp lực mạch máu phổi vì vậy làm giảm hậu gánh của thất phải. Kỹ thuạt IABP bơm bóng ở thời $\mathrm{g}=$ điểm khởi đầu thì tâm trương nên làm tăng huyết áp tâm trương và xả bóng ngay trước khi bắt đầu thì tâm thu nên làm giảm hậu gánh thất trái. Mức độ tác động của kỹ thuật IABP phụ thuộc vào các yếu tố.

- Thể tích bóng: thể tích máu được bóng hỗ trợ đẩy đi tỉ lệ thuận với thể tích bóng;

- Tần số tim: thời gian đổ đầy tâm trương của thất trái và động mạch chủ tỉ lệ nghịch với tần số tim; thời gian tâm trương càng ngắn thì thể tích bơm bóng càng nhỏ;

Tính đàn hồi của động mạch chủ: khi tính đàn

\footnotetext{
Bệnh viện Trung uoong Hué

Ngườ chịu trách nhiệm khoa họ: GS.TS. Bùi Đức Phú Ngày nhận bài: 05/04/2016 - Ngày Cho Phép Đăng: 05/05/2016

Phản Biện Khoa học: PGS.TS. Đặng Ngọc Hùng
}

GS.TS. Lê Ngoc Thành 
hồi này tăng (sức cản mạch máu hệ thống giảm), thì biên độ giãn nỡ của bóng sẽ giảm.

Bảng 1. Hiệu quả huyết động của kỹ thuật IABP

\begin{tabular}{|l|l|}
\hline \multicolumn{1}{|c|}{ Cơ quan } & \multicolumn{1}{c|}{ Hiệu quả tác động } \\
\hline Động mạch chủ & Giảm HA tâm thu, tăng HA tâm trương \\
\hline Tâm thất trái & $\begin{array}{l}\text { Giảm áp lực tâm thu, giảm áp lực cuối thì tâm trương, giảm thể tích thất } \\
\text { trái, giảm áp lực thành tâm thất trái }\end{array}$ \\
\hline Tim & Giảm hậu gánh, giảm tiền gánh, tăng cung lượng tim \\
\hline Lưu lượng tuần hoàn & Tăng lưu lượng tuần hoàn làm tăng tưới máu vành \\
\hline
\end{tabular}

3.1 Cân bằng cung cấp và nhu cầu tiêu thụ oxy co tim

Bơm bóng IABP trong thì tâm trương tạo ra chênh áp giữa động mạch chủ và tâm thất trái, giá trị chênh áp này còn được gọi là chỉ số thời gian áp lực tâm trương (DPTI). Kết quả là làm tăng lưu lượng tưới máu vành và vì vậy tăng cung cấp oxy cơ tim. Nhu cầu tiêu thụ oxy liên quan trực tiếp với diện tích bên dưới đường biểu diễn áp lực tâm thu thất trái, còn được gọi là chỉ số thời gian áp lực (TTI). Bóng được xả trong thì tâm thu giúp làm giảm hậu gánh thất trái, vì vậy làm tăng chỉ số TTI. Vì vậy tỷ lệ cung / cầu oxy (DPTI/TTI) sẽ tăng lên nếu như IABP hoạt động hiệu quả tối ưu, và điều này có thể được minh chứng bằng xét nghiệm định lượng thấy giảm nồng độ lactate trong máu lấy từ xoang vành.

\subsection{Lưu lượng tưới máu vành}

Theo định luật Hagen Poiseuille, lưu lượng dòng chảy đi qua một ống tỷ lệ thuận với chênh áp giữa 2 đầu ống và khẩu kính của ống, nhưng tỷ lệ nghịch với chiều dài đoạn ống và độ nhớt của chất lỏng chảy qua trong ống. vì vậy, ở bệnh nhân mắc bệnh động mạch vành thì cơ chế tự điều hòa bị tổn thương và lưu lượng vành là tương quan trực tiếp với huyết áp tâm trương. Vì vậy, IABP làm tăng huyết áp tâm trương do đó cải thiện tưới máu vành ở những bệnh nhân này.

\subsection{Chức năng thận}

Hỗ trợ bơm bóng đối xung trong động mạch chủ làm tăng cung lượng tim do đó có thể làm tăng thêm 25\% lưu lượng tưới máu thận. Lưu lượng nước tiểu có thể bị giảm sau khi thực hiện kỹ thuật IABP thường do vị trí bóng IABP ở thấp gần chỗ xuất phát động mạch thận.

\subsection{Huyết học}

Tác động cơ học của bơm bóng IABP làm tổn thương các tế bào hồng cầu gây huyết tán và làm giảm thấp thể tích huyết cầu có thể đến $5 \%$. Ngoài ra, tác động cơ học và liệu pháp kháng đông bằng heparin trong quá trình thục hiện IABP có thể gây huyết khối và giảm số lượng tiểu cầu hoặc cả hai.

\section{Chỉ định kỹ thuật bơm bóng đối xung}

\section{trong động mạch chủ}

Chỉ định và chống chỉ định của kỹ thuật bơm bóng đối xung trong động mạch chủ được tóm tắt trong bảng 2 . 
Bảng 2. Chỉ định và chống chỉ định sử dụng liệu pháp IABP

\begin{tabular}{|c|c|}
\hline \multicolumn{2}{|c|}{ Chỉ định } \\
\hline Tuyệt đối & Tương đối \\
\hline Nhồi máu cơ tim cấp & Suy thất trái trơ với điều trị nôi \\
\hline Sốc tim & Rối loạn nhịp thất trơ với điều trị nội \\
\hline Hở van 2 lá và thủng vách liên thất cấp tính & Bệnh lý cơ tim \\
\hline Thông tim và can thiệp mạch & Nhiễm khuẩn \\
\hline Đau thắt ngực không ổn định trơ với điều trị & Tim bẩm sinh phức tạp ở trẻ em \\
\hline Phẫu thuật tim & \\
\hline Mục đích để cai tuần hoàn ngoài cơ thể & \\
\hline \multicolumn{2}{|c|}{ Chống chỉ định } \\
\hline Tuyệt đối & Tương đối \\
\hline Hở van động mạch chủ & Nhiễm khuẫn không kiểm soát được \\
\hline Bóc tách động mạch chủ & Phình động mạch chủ bụng \\
\hline Bệnh lý tim giai đoạn cuối không hồi phục & Các rối loạn nhịp tim quá nhanh \\
\hline Stents động mạch chủ & Bệnh lý mạch máu ngoại vi nặng \\
\hline & Phẫu thuật tạo hình các động mạch lớn \\
\hline
\end{tabular}

\subsection{Nhồi máu co tim cấp}

Sử dụng IABP với mục đích duy trì huyết động ổn định trong khi chờ thực hiện liệu pháp điều trị đích hoặc chờ hồi phục. Thực hiện IABP giúp làm giảm công cơ tim và giảm sức cản mạch máu hệ thống, vì vậy các trường hợp hiện diện luồng thông trong tim, hở van 2 lá hoặc cả 2 loại thương tổn này sẽ giảm gây hậu quả, trong khi tưới máu vành sẽ được cải thiện.

Những trường hợp hở 2 lá nặng thứ phát do rối loạn chức năng hoặc đứt trụ cơ sau nhồi máu cơ tim có thể gây rối loạn huyết động nặng. Liệu pháp IABP rất hiệu quả trong những trường hợp này trong thời gian chờ phẫu thuật điều trị.

\subsection{Rối loạn nhịp thất}

Sử dụng IABO tỏ ra hiêu quả trong trường hợp rối loạn nhịp thất bất thường sau nhồi máu trơ với điều trị nội khoa nhờ tác động làm tăng áp lực tưới máu vành, làm giảm thiếu máu cơ tim và các nhồi máu xuyên thành cơ tim, đồng thời đảm bảo tưới máu hệ thống.

\subsection{Sốc tim}

Sốc tim là biến chứng đe dọa tính mạng sau nhồi máu cơ tim, đặc trưng với các dấu chứng như cung lượng tim giảm thấp, tụt huyết áp không đáp ứng với liệu pháp điều trị bù dịch, tăng áp lực đổ đầy và giảm tưới máu mô cơ quan dẫn đến thiểu và vô niệu, tăng lactate máu, và rối loạn tri giác. Liệu pháp IABP được xem là chỉ định nhóm I (khuyến cáo $\mathrm{ACC} / \mathrm{AHA}$ ) nhằm điều trị các trường hợp sốc tim mà không thể hồi phục nhanh với liệu pháp điều trị thuốc.

\section{4 Đau thắt ngục không ổn định}

Đau thắt ngực không ổn định trơ với điều trị thuốc là một chỉ định sử dụng IABP. Những bệnh nhân này thường có nguy cơ cao tiến triển đến nhồi máu cơ tim cấp và tử vong. Liệu pháp IABP có thể 
được thực hiện dễ dàng với kỹ thuật luồn catheter bóng qua da làm cải thiện tình trạng huyết động ở những bệnh nhân này hoặc với mục đích làm cầu nối chờ phẫu thuật điều trị.

\subsection{Suy tâm thất trơ với điều trị nội khoa}

IABP có vai trò quan trọng trong điều trị các trường hợp suy tâm thất không còn đáp ứng với điều trị thuốc không những do nhồi máu cơ tim gây ra mà có thể do các bệnh lý khác như bệnh cơ tim hoặc các trường hợp tổn thương cơ tim nghiêm trọng do viêm cơ tim do virus. Sử dụng IABP trong các trường hợp này với mục đích hỗ trợ trong thời gian chờ thực hiện các liệu pháp điều trị triệt để như cấy thiết bị hỗ trợ tâm thất hoặc ghép tim.

\subsection{Phẫu thuật tim}

IABP thường được sử dụng với mục đích điều trị ổn định huyết động cho những bệnh nhân nhồi máu cơ tim cấp trong trường hợp mổ cấp cứu. Hỗ trợ IABP thường được bắt đầu ở phòng thông tim can thiệp cho đến giai đoạn trong và sau mổ. IABP được sử dụng dự phòng cho những bệnh nhân có nguy cơ cao như hẹp tắc đáng kể thân chung, rối loạn chức năng thất trái nặng $(\mathrm{EF}<30 \%)$, suy tim xung huyết, bệnh cơ tim, suy thận mạn, hoặc các bệnh lý mạch máu não.

Các trường hợp khó cai tuần hoàn ngoài cơ thể có thời gian cặp động mạch chủ kéo dài, trường hợp phẫu thuật tái tạo mạch máu chỉ thực hiện được một phần, hoặc các bệnh nhân bị rối loạn chức năng cơ tim trước mổ. Khi cai tuần hoàn ngoài cơ thể có các biểu hiện nổi bật như tụt huyết áp với cung lượng tim giảm thấp, thì sử dụng IABP giúp làm tăng tưới máu vành và tưới máu hệ thống do đó giúp dễ dàng để cai bệnh nhân khỏi tuần hoàn ngoài cơ thể.

\section{Chống chỉ định kỹ thuật bơm bóng đối xung trong động mạch chủ}

Các chống chỉ sử dụng IABP được tóm tắt trong bảng 2 nói trên. Chống chỉ định ở những bệnh nhân bị hở van động mạch chủ vì nó làm nặng hơn tình trạng hở van. Những trường hợp khó luồn catheter IABP cần nghĩ đến bệnh lý bóc tách động mạch chủ vì gợi ý catheter bóng lạc đường qua lỗ tổn thương bóc tách sẽ làm cho tình trạng bóc tách động mạch chủ lan rộng hơn hoặc thậm chí gây vỡ động mạch chủ. Theo cơ chế tương tự, vỡ động mạch chủ có thể xảy ra khi luồn catheter IABP ở những bệnh nhân bị phình động mạch chủ bụng có kích thước lớn.

Những bệnh nhân mắc bệnh lý tim giai đoạn cuối không nên chỉ định sử dụng IABP trừ khi với mục đích làm cầu nối chờ cấy thiết bị hỗ trợ tâm thất hoặc chờ ghép tim. Nên tránh sử dụng IABP cho những bệnh nhân có bệnh lý mạch máu ngoại biên nghiêm trọng. việc luồn catheter bóng IABP qua da theo đường động mạch đùi là chống chỉ định ở bệnh nhân đã được phẫu thuật bắc cầu nối đùi khoeo. Các trường hợp nhiễm khuẩn không kiểm soát được và xuất huyết nội khó kiểm soát cũng là các chống chỉ định tương đối sử dụng IABP.

\section{Kỹ thuật luồn và vận hành catheter} bóng đối xung trong động mạch chủ

\subsection{Kỹ thuật đặt catheter bóng IABP}

Thiết bị IABP gồm 2 thành phần chính: (1) một catheter 2 nòng cỡ $8,0-9,5 \mathrm{~F}$ được thiết kế với một bóng có thể tích từ $25-50 \mathrm{ml}$ ở đầu xa; và (2) một hệ thống máy gồm 01 đầu bơm để bơm và xả bóng. Bóng catheter được làm bằng chất liệu polyethylene và được bơm phồng bằng khí trơ. Helium thường được sử dụng vì trong lượng riêng thấp nên dễ lưu chuyển từ hệ thống máy bơm vào bóng catheter. Helium cũng dễ được hấp thu trong máu trong trường hợp vỡ bóng.

Trước khi luồng catheter IABP, cần chọn bóng có kích thước phù hợp tùy chiều cao của bệnh nhân người lớn theo bảng 3 . Ngoài ra, còn có các bóng có kích thước nhở hơn để sử dụng trong trường hợp bệnh nhân nhi. Đường kính của bóng khi được bơm đầy không nên vượt quá 80-90\% đường kính của đoạn xuống của động mạch chủ ngực của người bệnh. 
Bảng 3. Chọn kích thước bóng catheter IABP (Datascope)

\begin{tabular}{|c|c|}
\hline Chiều cao thích hợp & Thể tích bóng catheter IABP \\
\hline Chiều cao dưới $152 \mathrm{~cm}$ & Bóng $25 \mathrm{ml}$ \\
\hline Chiều cao $152-163 \mathrm{~cm}$ & Bóng $34 \mathrm{ml}$ \\
\hline Chiều cao $164-183 \mathrm{~cm}$ & Bóng $40 \mathrm{ml}$ \\
\hline Chiều cao trên $183 \mathrm{~cm}$ & Bóng $50 \mathrm{ml}$ \\
\hline
\end{tabular}

Catheter IABP được luồn qua da theo đường vào từ động mạch đùi bên trong một máng dẫn theo kỹ thuật Seldinger. Có thể chọn các đường vào khác từ động mạch dưới đòn, động mạch nách, động mạch cánh tay, hoặc động mạch chậu. có thể luồn catheter IABP nhờ phẫu thuật mở ngực hoặc đường mở ngang thắt lưng, nhưng điều này làm tăng nguy cơ tử vong trong quá trình thực hiện thủ thuật.

Kỹ thuật luồn catheter IABP thường dưới hướng dẫn bởi màng hình tăng sáng hướng vào trong đoạn xuống của động mạch chủ ngực, với đầu mút của catheter ngang mức cách điểm xuất phát của động mạch dưới đòn trái khoảng $2-3 \mathrm{~cm}$ (ngang mức carina). Kỹ thuật luồn catheter IABP trong mổ có thể hướng dẫn bởi siêu âm qua đường thực quản.

Nòng bao phủ bên ngoài của catheter là đường di chuyển của khí helium vào bóng và nòng bên trong là đường theo dõi huyết áp động mạch xâm nhập. Các biến chứng của kỹ thuật IABP được nêu trong bảng 4 .

\section{Bảng 4. Biến chứng của kỹ thuật IABP}

\begin{tabular}{|l|}
\hline Mất mạch ngoại biên thoáng qua \\
\hline Thiếu máu chi \\
\hline Thuyên tắc huyết khối \\
\hline Hội chứng chèn ép khoang \\
\hline Bóc tách động mạch chủ \\
\hline Vết thương mạch máu tại vị trí luồn catheter vào gây giả phình, tụ máu, chảy máu \\
\hline Nhiễm trùng \\
\hline Vỡ bóng catheter (có thể gây thuyên tắc do khí) \\
\hline Biến chứng huyết học như giảm tiểu cầu, tán huyết \\
\hline Đặt catheter sai vị trí gây tổn thương não hoặc thận \\
\hline Chèn ép tim \\
\hline
\end{tabular}

6.1 Vận hành bơm bóng đối xung trong động mạch chủ IABP

Hệ thống máy IABP được lập trình cài đặt một mức trigger khởi phát việc bơm và xả bóng. Hầu hết các trường hợp đều sử dụng tín hiệu khởi phát là dạng sóng điện tâm đồ và dạng sóng huyết áp động mạch. Cài đặt bơm bóng vào thời điểm khởi đầu thì tâm trương, tương ứng với điểm giữa của sóng $T$. cài đặt xả bóng vào thời điểm khởi đầu của thì tâm thu, tương ứng với dỉnh của sóng $\mathrm{R}$. 
trường hợp tín hiệu ECG có chất lượng kém, bị nhiễu sóng và rối loạn nhịp tim có thể làm cho hoạt động bơm và xả bóng không khớp với cài đặt.

Cài đặt bơm bóng vòa thời điểm sau khi đóng van động mạch chủ, tương ứng với nóc dội nghịch trên đường điểu diễn dạng sóng huyết áp động mạch; và cài đặt xả bóng ngay trước thời điểm mở van động mạch chủ, tương ứng với điểm ngay trước đoạn lên của đường biểu diễn dạng sóng huyết áp. Việc điều chỉnh thời gian bơm và xả bóng phải tương ứng với chu chuyển tim. Chu chuyển tim được theo dõi liên tục trên màn hình theo dõi dạng sóng huyết áp động mạch.

Theo dõi thời điểm bơm bóng trên dạng sóng huyết áp vào thời điểm khởi phát thì tâm trương sẽ xuất hiện một hình ngấn chữ $\mathrm{V}$ ở nóc dội nghịch (hình 1). Tác động bơm bóng làm tăng huyết áp tâm trương tạo thêm một đỉnh thứ 2 trên dạng sóng huyết áp động mạch. Đỉnh thứ 2 này phản ánh tác động bơm hỗ trợ áp lực trong thì tâm trương. Tác động hỗ trợ là lý tưởng khi đỉnh thứ 2 này cao hơn dỉnh huyết áp tâm thu của bản thân người bệnh. Tùy thuộc vào tình trạng huyết động của bệnh nhân, lập trình hoạt động bơm bóng hỗ trợ tương ứng với mỗi nhát bóp của tim theo tỉ lệ 1:1 hoặc vài nhát bóp tim mới hỗ trợ 1 lần theo các tỉ lệ 1:2; 1:4; hoặc 1:8. Khi huyết động cải thiện, có thể cai hỗ trợ IABP bằng cách giảm dần tần số nhát bơm bóng hỗ trợ trước khi ngừng IABP hoàn toàn. Tuy nhiên, không bao giờ ngừng hoạt động IABP hoàn toàn nếu như còn lưu catheter bóng để tránh tạo huyết khối gây thuyên tắc.

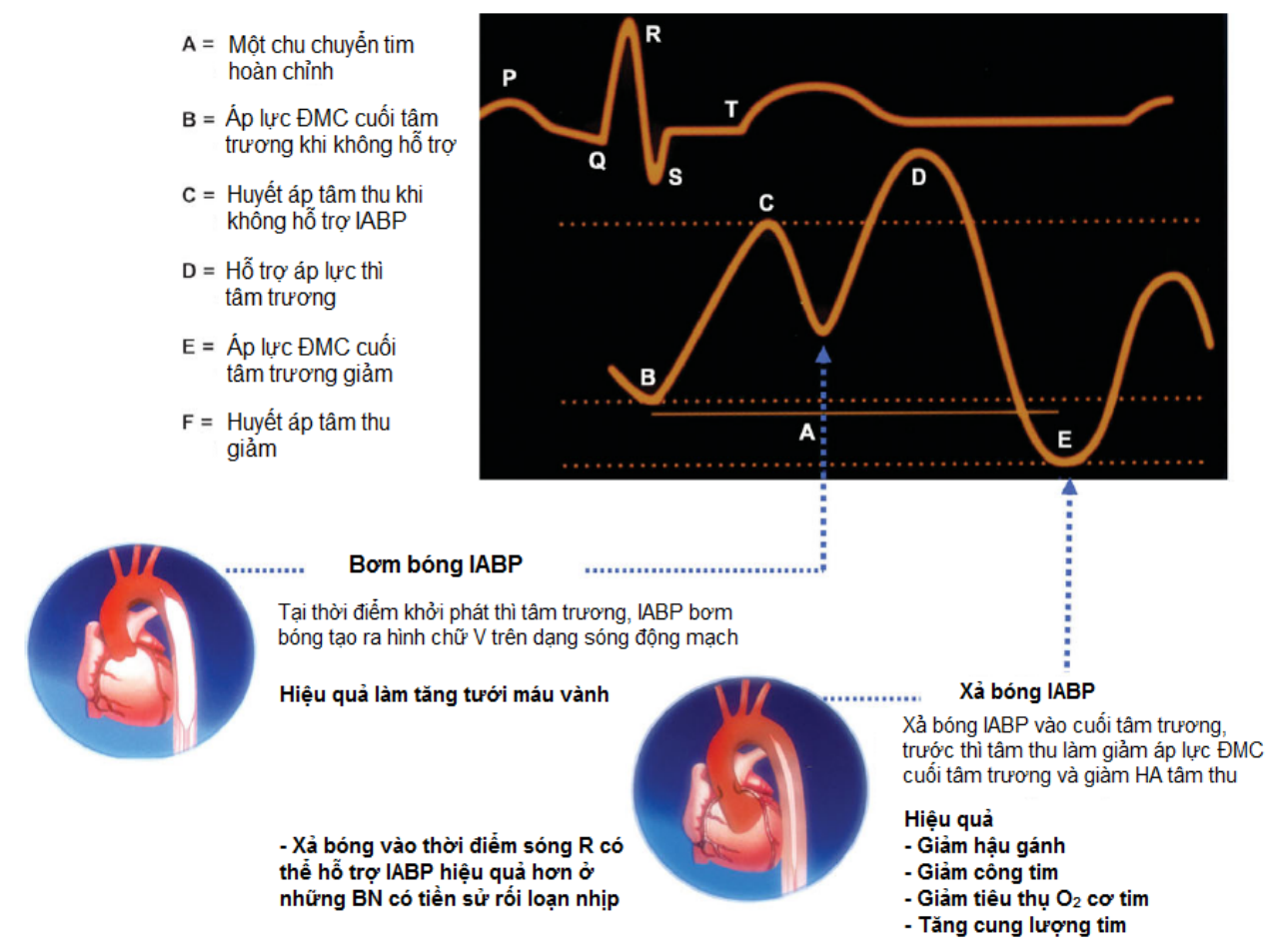

\section{Hình 1. Một chu chuyển tim hoàn chỉnh và dạng sóng tương úng của hoạt động IABP}

Nếu điều chỉnh IABP hoạt động không đạt tối ưu dẫn đến tình trạng huyết động không ổn định (hình $2_{\text {A-D }}$ ) biểu hiện một số tình huống sau:

- Bơm bóng sớm: bơm bóng trước khi van động mạch chủ đóng (hình $2_{\mathrm{A}}$ );

- Bơm bóng muộn: bơm bóng sau khi đóng van động mạch chủ (hình $2_{\mathrm{B}}$ );

- Xả bóng sớm: bóng xả trong thì tâm trương (hình $2_{\mathrm{C}}$ );

- Xả bóng muộn: bóng xả sau thời điểm khởi phát của thì tâm thu (hình $2_{\mathrm{D}}$ ). 


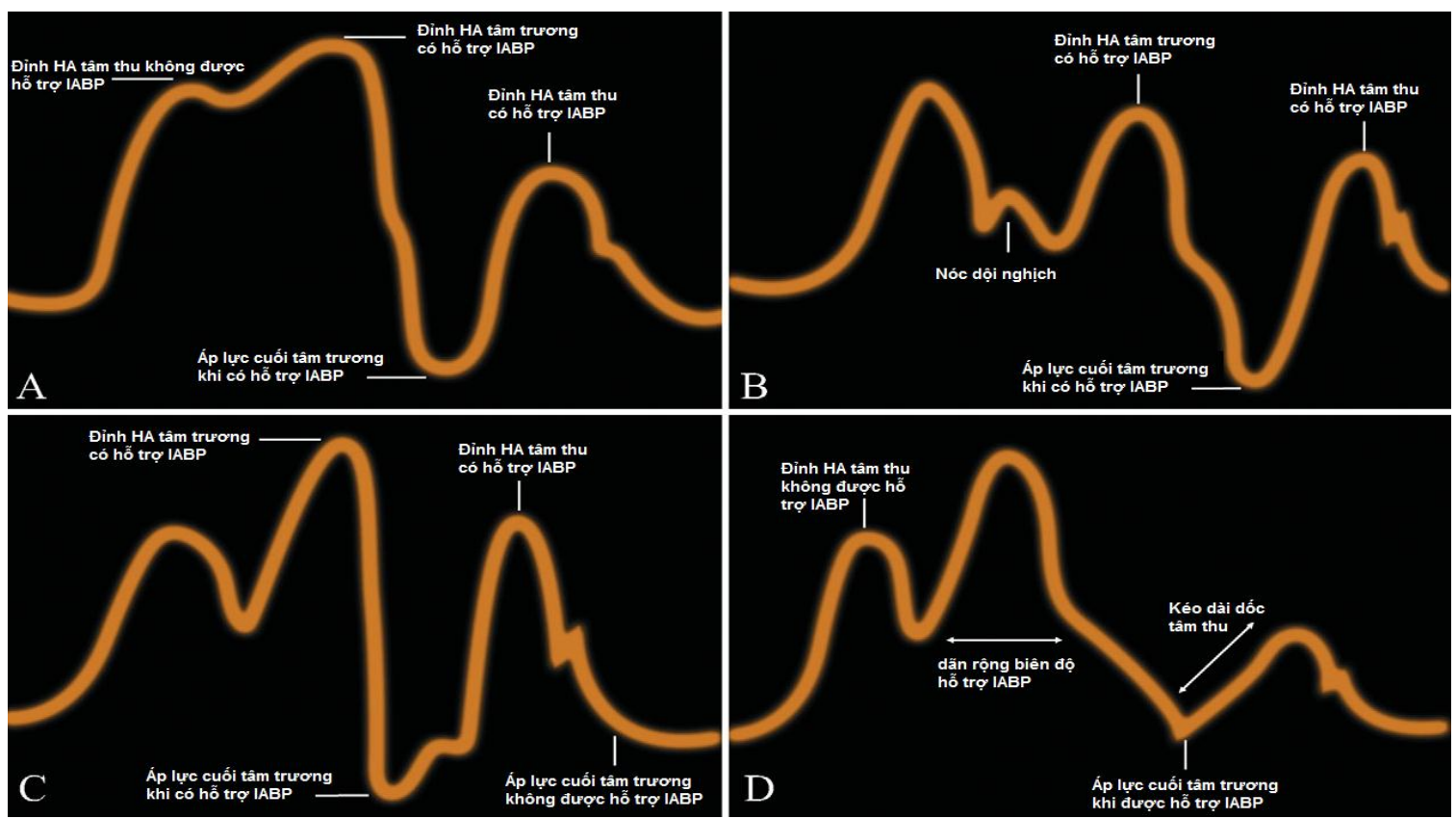

Hình 2. Hình ảnh dạng sóng áp lục một số tình huống IABP hỗ trọ không tối uu

(A) Đặc điểm dạng sóng khi bơm bóng IABP đến sớm trước nóc dội nghịch; một phần hỗ trợ IABP rơi vào thì tâm thu. Hậu quả:

- Van động mạch chủ đóng sớm;

- Tăng thể tích và áp lực đổ đầy thất trái cuối thì tâm trương (LVEDV và LVEDP) hoặc tăng áp lực động mạch phổi bít (PAWP);

- Tăng áp lực thành tâm thất trái hoặc tăng hậu gánh;

- Hở van động mạch chủ;

- Tăng nhu cầu tiêu thụ oxy cơ tim $\left(\mathrm{MVO}_{2}\right)$.

(B) Đặc điểm dạng sóng khi bơm bóng IABP đến muộn sau nóc dội nghịch; xuất hiện hình chữ V. Hậu quả: tưới máu vành không được tối ưu.

(C) Đặc điểm dạng sóng khi xả bóng IABP sớm thấy hình nhọn giảm diện tích hỗ trợ IABP. Hỗ trợ tâm trương không đạt tối ưu; áp lực cuối tâm trương bằng hoặc thấp hơn so với khi không hỗ trợ IABP; HA tâm thu có thể tăng. Hậu quả:

- Tưới máu vành không đạt được tối ưu;

- Nguy cơ ngược chiều dòng máu tưới vành hoặc động mạch cảnh;

- Tác dụng giảm hậu gánh không đạt tối ưu;

- Tăng nhu cầu tiêu thụ oxy cơ tim $\left(\mathrm{MVO}_{2}\right)$.

(D) Đặc điểm dạng sóng khi xả bóng IABP muộn thấy áp lực cuối tâm trương bằng so với khi không hỗ trợ IABP; đoạn dốc HA tâm thu kéo dài; dãn rộng biên độ hỗ trợ IABP. Hậu quả:

- Hầu như không có tác dụng giảm hậu gánh;

- Tăng nhu cầu tiêu thụ oxy cơ tim $\left(\mathrm{MVO}_{2}\right)$ bởi vì thất trái khi co bóp gặp sức cản lớn và kéo dài pha co bóp tim đẳng tích.

Hậu quả IABP có thể làm cản trở tống máu thất trái và làm tăng hậu gánh. 


\subsection{Cai hỗ trọ bơm bóng đối xung trong động mạch chủ IABP}

Cai hỗ trợ IABP nên được tiến hành khi thuốc trợ tim inotrope đang sử dụng ở liều thấp. điều này cho phép có thể tăng liều thuốc nếu cần thiết. Tiến hành cai hỗ trợ IABP chậm $(6-12$ giờ) bằng cách giảm dần tỉ lệ hỗ trợ nhát bóp tim với tần số hỗ trợ từ $1: 1$ đến $1: 2$ và thấp hơn nếu huyết động dung nạp tốt; hoặc bằng cách giảm dần thể tích bơm bóng hỗ trợ. Khuyến cáo không bao giờ ngắt hoạt động bóng IABP hoàn toàn khi còn lưu catheter vì nguy cơ hình thành huyết khối. giai đoạn này chăm sóc bệnh nhân IABP với các mục tiêu sau:

- Theo dõi và đánh giá tình trạng huyết động, tưới máu các cơ quan, và sự thuyên giảm các triệu chứng tim mạch;

- Theo dõi và phát hiện các dấu hiệu sớm của các biến chứng như thiếu máu chi, bóng catheter IABP bị lạc không đúng vị trí, hình thành huyết khối, chảy máu và nhiễm trùng;

- Đảm bảo IABP vận hành hiệu quả, bao gồm theo dõi điều chỉnh thời gian hỗ trợ bóng IABP phù hợp, hoạt động khởi phát hỗ trợ IABP và hệ thống báo động nhằm đạt được hiệu quả tối ưu trong quá trình hỗ trợ IABP.

\section{TÀI LIỆU THAM KHẢO}

1.Arafa OE, Geiran OR, Svennevig JL. Transthoracic intra-aortic balloon pump in open heart operations: techniques and outcome. Scand Cardiovasc J 20011; 35: 40-4

2.Bergman HE, Casarella WJ. Percutaneous intraaortic balloon pumping: initial clinical experience. Ann Thorac Surg 2008; 29: 153-5

3.Harken DE. The surgical treatment of acquired valvular disease. Circulation 2008; 18: 1-6
4.Kantrowitz A. Experimental augmentation of coronary flow by retardation of the arterial pressure pulse. Surgery 2003; 34: 678-87

5.Mercer D, Doris P, Salerno TA. Intra-aortic balloon counterpulsation in septic shock. Can J Surg 2011; 24: 643-5

6.Miller RD. Miller's anaesthesia. In: Nyhan D, Johns RA eds. Anesthesia for Cardiac Surgery. Elsevier, 2011

7.Moulopoulos SD, Topaz SR, Kolff WJ. Extracorporeal assistance to the circulation and intraaortic balloon pumping. Trans Am Soc Artif Intern Organs 2012; 8: 85-9

8. Pinkney KA, Minich LL, Tani LY et al. Current results with intraaortic balloon pumping in infants and children. Ann Thorac Surg 2012; 73: 887-91

9.Ryan TJ, Antman EM, Brooks NH et al. 2009 update: ACC/AHA Guidelines for the Management of Patients with Acute Myocardial Infarction: Executive Summary and Recommendations: A Report of the American College of Cardiology/American Heart Association Task Force on Practice Guidelines (Committee on Management of Acute Myocardial Infarction). Circulation 2009; 100: 1016-30

10. Velez CA, Kahn J. Compartment syndrome from balloon pump. Catheter Cardiovasc Interv 2010; 51: 217-9

11. Walls JT, Boley TM, Curtis JJ, Silver D. Heparin induced thrombocytopenia in patients undergoing intra-aortic balloon pumping after open heart surgery. ASAIO J 2012; 38: M574-6. 